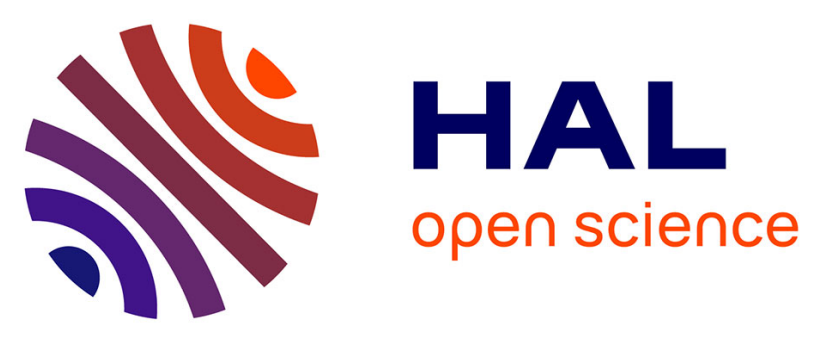

\title{
Impact of Vat resistance in melon on viral epidemics and genetic structure of virus populations
}

\author{
Alexandra Schoeny, Cecile Desbiez, Pauline Millot, Catherine Wipf-Scheibel, \\ Karine Nozeran, Patrick Gognalons, Hervé Lecoq, Nathalie Boissot
}

\section{- To cite this version:}

Alexandra Schoeny, Cecile Desbiez, Pauline Millot, Catherine Wipf-Scheibel, Karine Nozeran, et al.. Impact of Vat resistance in melon on viral epidemics and genetic structure of virus populations. Virus Research, 2017, 241, pp.105-115. 10.1016/j.virusres.2017.05.024 . hal-01535203

\section{HAL Id: hal-01535203 \\ https://hal.science/hal-01535203}

Submitted on 26 May 2020

HAL is a multi-disciplinary open access archive for the deposit and dissemination of scientific research documents, whether they are published or not. The documents may come from teaching and research institutions in France or abroad, or from public or private research centers.
L'archive ouverte pluridisciplinaire HAL, est destinée au dépôt et à la diffusion de documents scientifiques de niveau recherche, publiés ou non, émanant des établissements d'enseignement et de recherche français ou étrangers, des laboratoires publics ou privés.

\section{다(1)(2)}

Distributed under a Creative Commons Attribution - ShareAlikel 4.0 International 


\section{Accepted Manuscript}

Title: Impact of Vat resistance in melon on viral epidemics and genetic structure of virus populations

Authors: Schoeny Alexandra, Desbiez Cécile, Millot Pauline, Wipf-Scheibel Catherine, Nozeran Karine, Gognalons Patrick, Lecoq Hervé, Boissot Nathalie

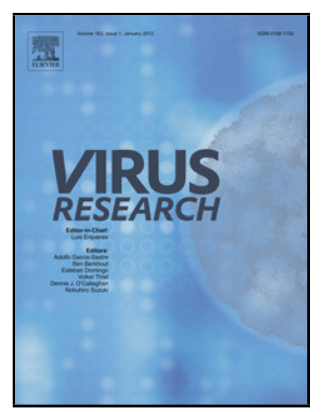

PII: S0168-1702(17)30140-5

DOI: http://dx.doi.org/doi:10.1016/j.virusres.2017.05.024

Reference: VIRUS 97152

To appear in: $\quad$ Virus Research

Received date: $\quad 9-2-2017$

Revised date: $\quad 30-5-2017$

Accepted date: $\quad 30-5-2017$

Please cite this article as: Alexandra, Schoeny, Cécile, Desbiez, Pauline, Millot, Catherine, Wipf-Scheibel, Karine, Nozeran, Patrick, Gognalons, Hervé, Lecoq, Nathalie, Boissot, Impact of Vat resistance in melon on viral epidemics and genetic structure of virus populations.Virus Research http://dx.doi.org/10.1016/j.virusres.2017.05.024

This is a PDF file of an unedited manuscript that has been accepted for publication. As a service to our customers we are providing this early version of the manuscript. The manuscript will undergo copyediting, typesetting, and review of the resulting proof before it is published in its final form. Please note that during the production process errors may be discovered which could affect the content, and all legal disclaimers that apply to the journal pertain. 


\section{Impact of Vat resistance in melon on viral epidemics and genetic structure of virus populations}

Schoeny Alexandra ${ }^{1 *}$, Desbiez Cécile ${ }^{1}$, Millot Pauline ${ }^{1}$, Wipf-Scheibel Catherine ${ }^{1}$, Nozeran Karine $^{1}$, Gognalons Patrick ${ }^{1}$, Lecoq Hervé ${ }^{1}$, Boissot Nathalie ${ }^{2}$

${ }^{1}$ Pathologie Végétale, INRA, 84140, Montfavet, France

${ }^{2}$ Génétique et Amélioration des Fruits et Légumes, INRA, 84140, Montfavet, France *Corresponding author : alexandra.schoeny@inra.fr

\section{Highlights}

- We evaluated the melon Vat-mediated resistance to virus in eight field trials.

- Vat always reduced the epidemics of CABYV.

- The reduction on CMV epidemics was irregular.

- Vat had a limited impact on WMV epidemics.

- Vat had no effect on the genetic structure of CABYV and WMV populations. 


\section{Abstract}

Cultivar choice is at the heart of cropping systems and resistant cultivars should be at the heart of disease management strategies whenever available. They are the easiest, most efficient and environmentally friendly way of combating viral diseases at the farm level. Among the melon genetic resources, Vat is a unique gene conferring resistance to both the melon aphid Aphis gossypii and the viruses it carries. The 'virus side' of this pleiotropic phenotype is seldom regarded as an asset for virus control. Indeed, the effect of Vat on virus epidemics in the field is expected to vary according to the composition of aphid populations in the environment and long-term studies are needed to draw a correct trend. Therefore, the first objective of the study was to re-evaluate the potential of Vat to reduce viral diseases in melon crops. The second objective was to investigate the potential of Vat to exert a selection pressure on virus populations. We monitored the epidemics of Cucurbit aphid-borne yellows virus (CABYV), Cucumber mosaic virus (CMV), Watermelon mosaic virus (WMV) and Zucchini yellow mosaic virus (ZYMV) in two melon lines having a common genetic background, a resistant line (R) and a susceptible line (S), in eight field trials conducted in southeastern France between 2011 and 2015. Vat had limited impact if any on WMV epidemics probably because A. gossypii is not the main vector of WMV in the field, but a favorable impact on CMV, yet of variable intensity probably related to the importance of A. gossypii in the total aphid population. Vat had a significant impact on CABYV epidemics with mean incidence reduction exceeding $50 \%$ in some trials. There was no effect of Vat on the structure of virus populations, both for the nonpersistent WMV transmitted by numerous aphid species and for the persistent CABYV transmitted predominantly by A. gossypii. 
Keywords: Aphis gossypii, Cucumis melo, genetic resistance, Gompertz model, selection pressure

\section{Introduction}

Pathogenic plant viruses generate economic losses by adversely affecting plant growth and reproduction, causing death of host tissues and plants, sterility, reduction of yield or quality, increased susceptibility to other stresses, loss of aesthetic value, quarantine and eradication of infected plants, as well as the cost of implementing control methods (Bos, 1982; Waterworth and Hadidi, 1998). Although crop losses are complex to assess, it was estimated that about $4 \%$ of global crop production is lost due to pathogenic plant viruses (Popp and Hantos, 2011). To prevent viral diseases, plants have evolved diverse resistance mechanisms (Soosaar et al., 2005). Recessive resistance is often related to mutation(s) in one of the plant genes required by the virus to complete a particular step of its infectious cycle (Caranta and Dogimont, 2008). Dominant resistance is mostly related to genes encoding nucleotide-binding leucine-rich repeat (NLR) proteins that recognize virus avirulence factors through 'gene-for-gene' interactions (Boualem et al., 2016). The recognition is followed by a rapid induction of programmed cell death at the site of virus inoculation and in the adjacent cells, which manifests as a hypersensitive response (HR). NLR genes usually confer a narrow resistance spectrum restricted to a single virus species. The Vat gene in melon (Cucumis melo) is an exception. Vat confers resistance to both the melon aphid Aphis gossypii and the viruses it carries (Boissot et al., 2016a). This pleiotropic phenotype was first evidenced in the early 1980s (Pitrat and Lecoq, 1980, 1982). Vat resistance to virus is triggered by an effector present in the saliva of the aphid 
transmitting the virus (Boissot et al., 2016a) and is efficient against any non-persistently aphidtransmitted virus inoculated by A. gossypii (Lecoq et al., 1980).

The melon aphid A. gossypii is widespread across all continents. The species is structured in host races (Boissot et al., 2016a). Clones belonging to the Cucurbit host race are able to colonize melon crops, causing leaf-curling, stunting and even plant death when colonization is intense. A. gossypii is also a known vector for over 50 plant viruses (Blackman and Eastop, 2000). In particular, it is an efficient vector of four viruses frequently observed on melon crops in France: Cucurbit aphid-borne yellows virus (CABYV, Polerovirus, Luteoviridae), Cucumber mosaic virus (CMV, Cucumovirus, Bromoviridae), Watermelon mosaic virus (WMV, Potyvirus, Potyviridae) and Zucchini yellow mosaic virus (ZYMV, Potyvirus, Potyviridae). CABYV induces yellowing of the older leaves, flower abortion and reduced number of fruits per plant. It is restricted to phloem tissues of infected plants and requires long aphid feeding periods (several hours to days) to be acquired and inoculated efficiently (persistent non-propagative transmission). This requirement is only met through feeding by a colonizing aphid species, which is the case for A. gossypii on melon crops. CMV, WMV and ZYMV cause mosaic symptoms on leaves, plant stunting and yield reduction (Lecoq and Desbiez, 2012). Severe infections of WMV and ZYMV also induce leaf deformation and mosaic on fruit, and ZYMV is also known to induce marbling and hardening of the flesh of fruit. CMV, WMV and ZYMV are acquired and inoculated during brief feeding probes (less than $1 \mathrm{~min}$ ) in the epidermal cells (non-persistent transmission). This matches the behaviour of transient aphids which alight, probe and fly away if the plant is not a suitable host. Thus, A. gossypii but also many other noncolonizing aphid species can be involved in the spread of these three latter viruses in melon crops.

Vat-mediated resistance has been early used in breeding programmes and the first melon cultivar carrying Vat (Margot) was listed in the French official catalog of varieties in 1987. 
Since then, more than a hundred cultivars reported as resistant to A. gossypii have been released in France and $80 \%$ of the melon crops cultivated in southeastern France are believed to carry Vat (Boissot et al., 2016a). Although adapted clones have been characterized (Boissot et al., 2016b), these cultivars still represent an efficient option to control A. gossypii. On the contrary, the 'virus side' of Vat pleiotropic phenotype is seldom regarded as an asset for virus control. In controlled conditions, Vat was shown to confer resistance to CMV, WMV and ZYMV when inoculated by A. gossypii (Lecoq et al., 1979, 1980; Boissot et al., 2016b) but Vat-carrying plants remained susceptible when viruses were inoculated mechanically or by other aphid species including A. craccivora, A. fabae and Myzus persicae (Lecoq et al., 1979, 1980). The effect of Vat on virus epidemics in the field has been poorly documented so far (Boissot et al., 2016a). It is expected to vary according to the composition of aphid populations in the environment but long-term studies are needed to draw an accurate trend. Therefore, the first objective of our study was to re-evaluate the potential of Vat to reduce viral epidemics in melon crops. Moreover, the effect of a virus resistance triggered by aphids on virus population genetic diversity in the field is not known. So, our second objective was to investigate the potential of Vat to exert selection pressure on virus populations. 


\section{Materials and methods}

\subsection{Field experiments}

Eight field experiments were conducted at INRA St Paul experimental station in Avignon

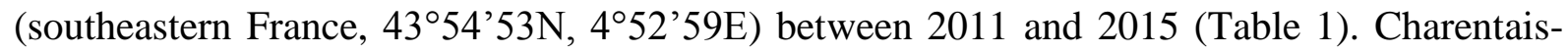
type melon plants were from two quasi-isogenic lines, a resistant line (R) and a susceptible line (S). The R line was derived from a cross between PI 161375, a Chinensis line carrying Vat, and a Cantalupensis line. The $\mathrm{F}_{1}$ was backcrossed with a Charentais-type cultivar that served as recurrent parent; progenies were selected for Vat resistance for the next backcross. Fifteen backcrosses were done, the last 8 with the Charentais $\mathrm{T}$ line which served as susceptible line in this study. Charentais T does not carry any known gene of resistance to virus. Seedlings were prepared in an insect-proof greenhouse three weeks before planting. Depending on the trial, plants at the 1-3 leaf stage were planted in late April or late May on dark brown plastic mulch with drip irrigation. Early plantings were protected from wind damage with Agryl P17 fleece (Fiberweb France, Biesheim) for 11-15 days. Each treatment consisted of one plot of 120 to 240 plants ( $0.5 \mathrm{~m}$ plant spacing) organized in 6 to 16 rows ( $1.5 \mathrm{~m}$ row spacing) depending on the trial.

\subsection{Plant sampling and virus detection}

In order to establish virus dynamics, melon plots were sampled at regular intervals, up to 11 times during the cropping season. The sampling campaign generally started one week after planting or fleece removal in order to detect early onset of virus infection. For trial P13, samplings were delayed due to cold post-planting weather conditions slowing down crop 
growth. A stratified random sampling design involving 24 to 40 plants per modality was established for each trial. Depending on the trial, strata consisted of one or two rows, and 4 to 5 plants were randomly chosen in each stratum. These tagged plants served for virus monitoring throughout the trial. Expanding leaves were sampled at each sampling date. It was assumed that information obtained from an expanding leaf will accurately reflect the status of the entire plant. CABYV, CMV, WMV and ZYMV were detected by double antibody sandwich enzyme-linked immunosorbent assay (DAS-ELISA) in four separate tests with specific polyclonal antisera produced in our laboratory. Virus detection was considered positive when the absorbance at $405 \mathrm{~nm}$ (Multiskan EX, Thermo Electron Corporation) was above 3 times that of the healthy controls. ZYMV was detected only in 2012, so it was not included in further analyses.

\subsection{Analyses of virus epidemics}

In a first step, we analyzed the effect of Vat on the infection probability of a plant by a given virus with a generalized linear model (procedure GENMOD of SAS software, version 9.3 for Windows, SAS Institute Inc., Cary, NC, USA). The dependent variable (presence/absence of a given virus in a sample) being binary, the model was based on a binomial distribution and a logit link function. Explanatory variables were Vat resistance and sampling time.

In a second step, we analyzed virus dynamics and examined the effect of Vat on their features. Binary variables were pooled by modality and date to calculate virus incidence (number of infected plants divided by the number of sampled plants) and to establish virus progress curves. Virus dynamics having a characteristic S-shape, nonlinear model fitting was applied to incidence data (procedure NLIN of SAS software). Among the models commonly used to characterize the temporal dynamics of plant viruses (Nutter, 1997), the Gompertz function was chosen as its three parameters $(\alpha, \beta, \gamma)$ make sense biologically for interpretation of the data: 


$$
y_{t}=\gamma e^{-\beta e^{-\alpha t}}
$$

$\mathrm{y}_{\mathrm{t}}$ is the incidence, expressed as a percentage, at time $\mathrm{t}$;

$\mathrm{t}$ is the thermal time expressed in degree-days (basis $12^{\circ} \mathrm{C}$, temperature below which melon growth is stopped);

$\alpha$ is linked to disease progress: when $\alpha$ increases, the epidemic is more rapid;

$\beta$ is linked to disease onset: when $\beta$ increases, the epidemic is delayed;

$\gamma$ is the asymptote, i.e., the carrying capacity: when $\gamma$ increases, maximum incidence is raised;

$\alpha, \beta$ and $\gamma$ are positive parameters, $\gamma$ is bounded above by 100 .

The area under the disease progress curve (AUDPC) was calculated for each virus dynamic. Values were standardized by dividing by the total duration of the monitoring in each trial, in order to approximate mean incidence over the epidemic (Nutter, 1997). On the basis of their mean incidence, epidemics were categorized as mild [0-20\%], intermediate [21-40\%], severe [41-60\%] or extreme [61-100\%].

For each virus, the effect of Vat on the three parameter estimates and mean incidence was investigated through a nonparametric sign test performed between $\mathrm{R}$ and $\mathrm{S}$ values (XLSTAT, version 2015.4.01, Addinsoft, Paris).

\subsection{Molecular analyses}

Molecular analyses focused on CABYV and WMV. Approximately 20 ELISA-positive samples were selected for each virus, each year and each condition (R/S). However, there were some variations in this number (from 9 to 39 ) in relation to the dynamics of the epidemics in each case (Table 2).

Total RNAs were extracted from ELISA-positive samples with TRI-reagent ${ }^{\circledR}$ following the manufacturer's recommendations. Fragments of the coat-protein $(\mathrm{CP})$ coding region were 
amplified using specific primers. For CABYV, a 536-nt fragment in the $\mathrm{CP}$ and movement protein (MP) coding region was amplified with primers CABYV-CE9 (Kassem et al., 2007) and CABYV-KN-3' (5'-CCGTTCCCCTTGTAGAGGAT-3'). For WMV, primers WVVIAM-5' and WMV-3' were used (Desbiez et al., 2009), yielding a 811-nt fragment encompassing the $\mathrm{N}$-terminal variable region of the $\mathrm{CP}$. The amplified fragments were sent for direct sequencing to Genoscreen (Lille, France). One sequence from each haplotype was submitted to GenBank.

Sequences were aligned with ClustalW included in MEGA6.06 (Tamura et al., 2013). Reference GenBank sequences were added for the analyses. The best substitution model was selected with MEGA. The absence of recombination signal in the different virus fragments analyzed was checked using 6 different recombination detection methods included in RDP4.0 (Martin et al., 2015). Distance and maximum-likelihood trees were built with MEGA using a bootstrap resampling $(n=500$ bootstraps). Haplotypic networks were drawn with Network 5.0.0.0 (http://www.fluxus-engineering.com/). Cumulated haplotypic frequencies 2011-2015 were compared between $\mathrm{R}$ and $\mathrm{S}$ melons with a paired t-test and a two-sided paired Wilcoxon nonparametric test using the Rcmdr package of $\mathrm{R}$ software (https://www.r-project.org/). Haplotypic richness in R and S melons was estimated for CABYV and WMV on the 2011-2015 cumulated data using Abundance-based Coverage Estimator (ACE) (Chao and Lee, 1992) calculated with SpadeR (https://chao.shinyapps.io/SpadeR/). 


\section{Results}

\subsection{Effect of Vat on virus epidemics}

The experimental setup consisted of eight melon field trials conducted in southeastern France between 2011 and 2015. CABYV, CMV and WMV were consistently observed every year. ZYMV was only observed in 2012 and consequently was not included in further analyses. Virus disease progress curves were successfully described by the Gompertz model in all cases except one (trial P11 where CMV incidence was $2.5 \%$ in the R melons at the end of the cropping cycle).

CABYV epidemics on $\mathrm{S}$ melons were variable in earliness and intensity (Figure 1). Disease onset mostly occurred during the three weeks following planting but infected plants could occasionally be detected as early as seven days after planting (P11), or conversely, 35 days after planting (V13). Disease progress varied from extremely rapid (V11) to slow (V12). Both earliness and progress rate get integrated in the calculation of the mean incidence (Table 3). Except one extreme epidemic (P11), CABYV epidemics were categorized as intermediate to severe.

Vat significantly reduced the probability of infection of a plant by CABYV in all trials (Table 4). In terms of effect on the virus dynamics, this translated into a significant reduction of parameter $\alpha$ of the Gompertz model (Table 3), meaning that CABYV incidence progress was slower on $\mathrm{R}$ melons than on $\mathrm{S}$ melons. The effects on parameter $\beta$ (linked to disease onset: when $\beta$ increases, the epidemic is delayed) and parameter $\gamma$ (carrying capacity: maximum incidence at harvest) were not significant, but Vat resulted in delayed disease onset by 6-14 days and/or reduced disease incidence at harvest stage, in 5/8 trials. Vat significantly reduced 
CABYV mean incidence (Table 3). In almost all trials, Vat permitted to shift from one epidemic category to the one below, with an average $37 \%$ reduction in mean incidence (range $12-57 \%$ ). CMV epidemics on S melons were seldom intermediate: they were either mild, or severe to extreme (Figure 2, Table 3). For the latter, disease onset mostly occurred during the two weeks following planting whereas delayed onsets (36-49 days after planting) mostly led to mild epidemics. Interestingly, when CABYV epidemics developed rapidly (V11, P11), CMV onset was late and progress was slow. Vat significantly reduced the probability of infection of a plant by CMV in 6/8 trials (Table 4). None of the Gompertz model parameter estimates were significantly affected by Vat although presence of the gene resulted in a 7-8 day delay in disease onset and/or a reduced incidence at harvest (Table 3). Vat significantly reduced CMV mean incidence permitting classification to one epidemic category below that of comparable plants without the Vat gene in half of the trials, with an average $31 \%$ reduction (range 5-83\%). The amount of reduction due to Vat was inversely proportional to mean incidence: for severe to extreme epidemics, the reduction induced by Vat was only $14 \%$.

WMV was generally the latest virus to be observed on S melons (Figure 3). Except in P15 where disease onset was noticed 15 days after planting, WMV symptoms were first observed after 7 weeks of cropping. Epidemics were mostly mild to intermediate. Vat had no significant decrease effect on the probability of infection of a plant by WMV except in P14 (Table 4). For this particular trial, Vat delayed disease onset by 8 days and reduced disease progress. Except for P14, no change in epidemic category was observed (Table 3). An oppposite trend, i.e., increase in viral incidence on Vat-carrying plants, was even observed in V12, P11 and P13.

\subsection{Effect of Vat on virus populations}


Preliminary data based on partial capsid gene sequences showed that the molecular variability of CMV was extremely low (data not shown) and ZYMV was present only in 2012. As a consequence, molecular analyses focused on CABYV and WMV.

For CABYV, 193 sequences were obtained, 79 for $\mathrm{R}$ and 114 for $\mathrm{S}$ plots (Table 2). Thirteen different haplotypes were characterized (Genbank KY586119-KY586131), including 5 haplotypes detected in only one plant each (singletons). Multiple infections of plants with two haplotypes differing by 1 or 2 mutations were observed in 13 cases. The overall variability of the virus was low over the 5 years (mean distance between haplotypes $=0.007$ ). Most haplotypes differed by only 1 to 3 mutations in the sequenced fragment, with the exception of the more divergent haplotype G observed in 2011, 2013 and 2015 (Figure 4a). There was no evidence for recombination in the sequenced region. The same major haplotypes were present in both $\mathrm{R}$ and $\mathrm{S}$ plots (Figure $4 \mathrm{~b}$ ) and the differences in frequencies were not significant between the plots ( $\mathrm{p}=0.14$, paired t-test). Haplotypic richness estimators (ACE) in R (9-42 haplotypes) and S (13-61 haplotypes) plots were largely overlapping, showing that the estimated total number of haplotypes was not significantly different between the two conditions. Comparison with isolates from throughout the world showed that all isolates from the assay were closely related to the original CABYV isolate from southwestern France (Lecoq et al., 1992) as well as to isolates from Egypt, Tunisia, Spain, Serbia and Czech Republic (Figure 5).

For WMV, 299 partial sequences were obtained, 153 for R and 146 for S plots (Table 2). Twenty-seven different haplotypes were present in the 712-nt sequences used for the analysis, including 13 singletons (Figure 6) (Genbank KY586092-KY586118). The estimated total number of haplotypes was not significantly different between R (24-141 haplotypes) and S (1844 haplotypes) melons. WMV populations in the trials belonged to four different molecular groups and subgroups already known to be present in southeastern France (Desbiez et al., 2009). Group CL was detected in one R plant in 2011, and at a low frequency in 2013, both in 
$\mathrm{R}$ and S melon plants (Figure 7). Within the EM group, subgroup EM1 was present every year and, except in 2014, was the most frequent (Figure 7). Subgroup EM3 was observed in 2014 both in R and S melon plants, and EM4 was detected at a low frequency every year except in 2012 (Figure 7). Ten plants displayed mixed infections between EM1 and one of the minor groups or subgroups present in the same year, and five samples also presented mixed infections with two haplotypes from the same subgroup and differing by 1 to 3 mutations. There was no evidence for recombination in the sequenced fragment. The major haplotypes were the same in $\mathrm{R}$ and $\mathrm{S}$ melon plants, and the differences in frequencies were not significant $(\mathrm{p}=0.625$, paired t-test). No mutations were observed in or close to the 'DAG' triplet in the N-terminal variable part of the coat protein, involved in aphid transmission (Lopez-Moya et al., 1999). 


\section{Discussion}

4.1. Virus epidemics

Eight field experiments were conducted in one of the main melon production areas in France. In the course of the study (2011-2015), CABYV, CMV and WMV were observed every year, whereas ZYMV was observed only in 2012, in agreement with the sporadic pattern described for this virus (Lecoq et al., 2009, 2014). Regardless of the planting date (late April or late May) CABYV and CMV were always detected first, generally 2-3 weeks after planting, leading to epidemics with mean incidence mostly intermediate to severe for CABYV and severe to extreme for CMV. WMV was always detected later, generally after 7 weeks of cropping, leading to epidemics mostly mild to intermediate. Since its first description in 1992 in France, CABYV has been detected in an ever-increasing number of countries and recent surveys indicate that CABYV is becoming one of the most common cucurbit viruses in a wide variety of areas (Kassem et al., 2007; Lecoq and Desbiez, 2012; Juarez et al., 2013).

There was a complete decoupling between the progress curves of the different viruses during a cropping season and between different seasons for a given virus, suggesting that biotic and/or abiotic factors involved in the epidemiology of these viruses are different.

Virus progress curves were successfully described by the Gompertz model in all cases except one. This model commonly used to characterize the temporal dynamics of plant viruses (Nutter, 1997) was in particular reported as the most appropriate to compare epidemics of aphidtransmitted viruses in melon crops in Spain (Alonso-Prados et al., 2003). Unlike the latter study where the linearized form of the model was used, nonlinear model fitting was applied to incidence data in our study, allowing the estimation of the three parameters of the model $(\alpha, \beta$, 
$\gamma$ ). The effect of Vat on the model parameter estimates and on the mean incidence (AUDPC divided by the epidemic duration) was investigated for each virus.

\subsection{Effect of Vat on CABYV}

Vat had a marked impact on CABYV epidemics. The mean incidence, calculated over the total duration of the epidemic, was significantly and consistently reduced. An average reduction of $37 \%$ was observed over the eight trials. Vat impacted the temporal progress of CABYV epidemics mostly by slowing down the infection rate as shown by the significant reduction of parameter $\alpha$ of the Gompertz model. Vat allowed to delay disease onset by 6-14 days in half of the trials.

These results suggest that a part of CABYV primary and secondary infections comes from $A$. gossypii clones that are controlled by Vat. The effect of Vat on CABYV has not been entirely characterized in the laboratory yet. Nevertheless, it was observed that A. gossypii has far less access to phloem on Vat-carrying plants than on susceptible plants (Chen et al., 1997; Klinger et al., 1998) and colonize Vat-carrying plants less than susceptible plants (Boissot et al., 2016a). This may explain the low transmission rate of CABYV by A. gossypii on Vat-carrying plants as suggested by preliminary results (Lecoq, 1999; unpublished data).

Although marked, the effect of Vat on CABYV epidemics was not total. Other aphid species such as Myzus persicae and Macrosiphum euphorbiae are known to be efficient vectors of CABYV (Lecoq and Desbiez, 2012), but they probably play a limited role in the epidemiology of CABYV in southeastern France. First, the relative abundance of these species within the winged aphid population visiting the melon crops was low (Schoeny, unpublished data) and second, they have never been observed colonizing melon crops in southeastern France (Lecoq, personal communication). Accordingly, using real-time quantitative RT-PCR, Kassem et al. 
(2013) found that $A$. gossypii was the species with the highest number of individuals carrying CABYV suggesting that it was the main aphid species involved in the spread of CABYV in melon crops in southeastern Spain. It is more plausible that the incomplete control of CABYV by Vat-carrying plants is related to transmission of the virus by A. gossypii clones able to colonize Vat-carrying plants. Such adapted clones were collected in southeastern France (Boissot et al., 2016b). They may explain why CABYV development was not totally controlled in $\mathrm{R}$ plots.

Vat had no impact on CABYV population structure. All CABYV isolates from the trials were closely related molecularly based on comparison of capsid gene sequences and showed also a high degree of similarity with the first CABYV isolate sequenced, originating from southwestern France (Lecoq et al., 1992). There was no evidence for recombination in the sequenced region, but longer sequences should be analyzed to confirm the absence of recombinants, because recombination has been described for other parts of the CABYV genome (Knierim et al., 2010). To date, the phylogeny of CABYV populations shows that Asian isolates differ from those collected in the Mediterranean region (Kassem et al., 2013). The French CABYV isolates all belong to the same molecular group, defined as 'IIb' based on Spanish isolates (Kassem et al., 2013) (Figure 5). All haplotypes defined in this study clustered together, with the exception of the divergent haplotype G observed 3 times during the assay in 2011, 2013 and 2015 in R and S melon plants. Its sequence was identical or very similar to some isolates from southeastern Spain that constitute a well-supported subgroup within group IIb. The lack of strong phylogenetic differentiation of CABYV populations in the Mediterranean basin is probably an indication of frequent long-distance exchanges, either through viruliferous aphids or via human transfers of infected plant material. Alternatively, the presence of the same haplotypes over multiple years in the assay could be due to maintenance of the virus in local reservoir host plants that occur frequently around the experimental plots (Lecoq et al., 1992; 
Lecoq and Desbiez, 2012). Although the Vat gene significantly reduced CABYV epidemics, the structure of virus populations was not significantly different in $\mathrm{R}$ and $\mathrm{S}$ crops, showing that the selective pressure exerted by Vat is weak, or that it applies to a few target sites that may not be located in the CP.

\subsection{Effect of Vat on CMV}

Vat significantly reduced CMV mean incidence. The intensity of the reduction was highly variable (5-83\%) and inversely proportional to mean incidence. The reduction became smaller with increasing incidence. None of the Gompertz model parameter estimates was significantly affected by Vat, although it occasionally induced a delay of 7-8 days in disease onset and/or a reduced incidence at harvest. So, the effect of Vat on the temporal progress of CMV epidemics was trial-dependent suggesting that biotic and/or abiotic factors involved in the epidemiology of this virus were variable among trials.

The partial effect of Vat on CMV epidemics in the field can be explained by different elements. First, the resistance to CMV triggered by A. gossypii is clone specific (Boissot et al., 2016b). All A. gossypii clones collected to date from Cucurbits in southeastern France have been found to trigger resistance to CMV in the laboratory. These clones belong to the Cucurbit host race, and numerous clones belonging to other host races also visit melon crops in the spring in southeastern France (Thomas et al., 2012). Clones not belonging to the Cucurbit host race may be viruliferous but may not elicit resistance to CMV in Vat-carrying plants. Second, many aphids in addition to $A$. gossypii species visit the melon crops (Schoeny, unpublished data) and do not trigger the resistance to CMV, as previously shown (Lecoq et al., 1979, 1980).

Interestingly, the Vat resistance to CMV appears to be highly durable as suggested by the absence of CMV evolution toward overcoming the gene (Boissot et al., 2016b). Moreover the 
low variability of CMV observed in this study (data not shown) also suggests that in fields, Vat resistance did not lead to selection of particular CMV isolates.

\subsection{Effect of Vat on WMV}

Vat had no favorable impact on WMV epidemics except in one trial for which Vat-carrying plants exhibited delayed disease onset by 8 days and reduced disease progress. Preliminary field studies already indicated that Vat had a very limited effect on WMV (Gray et al., 1986; Lecoq and Pitrat, 1989). As with CMV, the effect of Vat on WMV was characterized at the laboratory, but fewer A. gossypii clones were tested. Nevertheless, if we consider that clones that trigger resistance to CMV also trigger resistance to WMV, then the effect of Vat on CMV and WMV is expected to be similar in the field if both viruses are transmitted by the same aphid clones and/or species. Our results clearly showed that it was not the case and suggested that WMV was less frequently transmitted by A. gossypii than CMV. Spatial analyses also suggested that different aphid species could be the main vectors of CMV and WMV in melon crops in Spain (Alonso-Prados et al., 2003).

Vat had no impact on WMV population structure. Four of the molecular groups and subgroups already known to be present in southeastern France have been observed in the assay. This includes a 'classic' (CL) group that has been present in France for at least 40 years, as well as an 'emerging' group (EM) probably of Asian origin, observed in France since 2000, that is currently spreading in the Mediterranean basin and is locally replacing CL isolates (Desbiez et al., 2009; Lecoq and Desbiez, 2012). Subgroup EM1 was the most frequently observed over the past 15 years in an experimental plot $4 \mathrm{~km}$ away from where these assays were conducted (Lecoq et al., 2014). In this region, CL isolates were entirely replaced by EM1 isolates within a few years, possibly in relation to fitness differences in crops or reservoirs (Fabre et al., 2010; 
Lecoq et al., 2011, 2014), whereas CL and EM isolates seem to have reached an equilibrium in southeastern France (Desbiez et al., 2009; Fabre et al., 2010). No recombination was detected in the sequenced region in the assay. However, even though recombinants have been described in the CP coding region of WMV, recombination hotspots are located in other parts of the genome (Desbiez and Lecoq, 2008; Desbiez et al., 2011). The same molecular groups and subgroups were present in $\mathrm{R}$ and $\mathrm{S}$ melon plots, and the frequencies of the major haplotypes were not significantly different, indicating that Vat has no strong effect on the population structure of the non-persistently transmitted WMV. Accordingly, we showed that in most cases Vat had no effect on the development of WMV epidemics, and it was shown that WMV, like CMV, could not adapt to Vat-mediated resistance under experimental conditions (Boissot et al., 2016b).

\subsection{How to reinforce the efficiency of Vat?}

Because Vat does not reduce virus epidemics as expected by farmers for a resistance, Vat should be combined with other genes conferring resistance to the specific viruses. The seminal work by Lecoq and Pitrat $(1983,1989)$ based on PI 161375 melon line that carried both Vat and the oligogenic and partial recessive resistance to CMV 'common' strains (Guiu-Aragones et al., 2014) illustrates the fact that combining both types of resistance is of value. A recent work by Boissot et al. (2015) based on field data and modeling also suggested that combining Vat with an oligogenic resistance to CABYV (Dogimont et al, 1997; Kassem et al., 2015) may increase the efficiency of CABYV resistance on the long term.

Resistant cultivars should be at the heart of virus disease management strategies whenever available. Complementary practices could be associated to ensure an efficient and durable virus control. In particular, cultural practices intended to delay or reduce virus spread such as weeding 
to remove virus reservoirs and the use of plastic mulches acting as aphid repellent have been shown to be partially efficient (Lecoq and Pitrat, 1989). An appropriate manipulation of field margins could also contribute to regulate the populations of aphids and/or their virus load. For example, flower strips can participate in aphid biological control by favoring natural enemies (Pfiffner and Wyss, 2004) and strips of non-host plants can protect crops from non-persistently aphid-transmitted viruses by allowing aphids to probe on healthy plants and thus to lose their virus load before reaching the crops (Hooks and Fereres, 2006). So, combining Vat resistance with sown flower strips could possibly enhance virus control in melon crops. Such innovative cropping systems remain to be tested. 


\section{Acknowledgements}

We thank Joël Béraud, Michel Pascal, Frédéric Pascal and Pascale Mistral for their efficient

help in field experiments, Benoît Moury and two anonymous reviewers for constructive comments on this manuscript. This study was funded by INRA (AAP2010 Gestion durable des résistances-ParcelR), Agence Nationale de la Recherche (ANR-2010-STRA-001-01 VirAphid) and Ministère de l'Agriculture, de l'Alimentation et de l'Environnement (CTPS 25-C-2011-09 and CASDAR 12-1278 Agath). 


\section{References}

Alonso-Prados, J.L., Luis-Arteaga, M., Alvarez, J.M., Moriones, E., Batlle, A., Lavina, A., Garcia-Arenal, F. and Fraile, A. (2003) Epidemics of aphid-transmitted viruses in melon crops in Spain. Eur. J. Plant Pathol. 109(2), 129-138.

Blackman, R.L. and Eastop, V.F. (2000) Aphids on the world's crops. An identification and information guide. $2^{\text {nd }}$ edition. John Wiley and Sons, Chichester, 466 pp.

Boissot N., Schoeny A., Millot P., Wipf-Scheibel C., Nozeran K., Lecoq H. and Fabre F. (2015) Gérer les épidémies virales en combinant résistances aux virus et résistances aux pucerons : quel intérêt? Innov. Agron. 46, 127-135.

Boissot, N., Schoeny, A. and Vanlerberghe-Masutti, F. (2016a) Vat, an amazing gene conferring resistance to aphids and viruses they carry: from molecular structure to field effects. Frontiers Plant Sci. 7(1420), 1-18.

Boissot, N., Thomas, S., Chovelon, V. and Lecoq, H. (2016b) NBS-LRR-mediated resistance triggered by aphids: viruses do not adapt; aphids adapt via different mechanisms. BMC Plant Biol. 16(25), 1-12.

Bos, L. (1982) Crop losses caused by viruses. Crop Prot. 1, 263-282

Boualem, A., Dogimont, C. and Bendahmane, A. (2016) The battle for survival between viruses and their host plants. Curr. Opin. Virol. 17, 32-38. 
Caranta, C. and Dogimont C. (2008) Plant resistance to viruses: Natural resistance associated with recessive genes. In: Mahy B. W. J. and Van Regenmortel M. H. V.(Eds.), Encyclopedia of Virology, vol. 5, third ed. Elsevier, Oxford, pp. 177-186.

Chao, A. and Lee, S-M. (1992). Estimating the number of classes via sample coverage. J. Am. Stat. Assoc. 87, 210-217.

Chen J.Q., Rahbé Y., Delobel B., Sauvion N., Guillaud J. and Febvay G. (1997) Melon resistance to the aphid Aphis gossypii: behavioural analysis and chemical correlations with nitrogenous compounds. Entomol. Exp. Appl. 85, 33-44.

Desbiez, C., Joannon, B., Wipf-Scheibel, C., Chandeysson, C. and Lecoq, H. (2009) Emergence of new strains of Watermelon mosaic virus in South-Eastern France: evidence for limited spread but rapid local population shift. Virus Res. 141, 201-208.

Desbiez, C., Joannon, B., Wipf-Scheibel, C., Chandeysson, C. and Lecoq, H. (2011) Recombination in natural populations of watermelon mosaic virus: new agronomic threat or damp squib? J. Gen. Virol. 92, 1939-1948.

Desbiez, C. and Lecoq, H. (2008) Evidence for multiple intraspecific recombinants in natural populations of Watermelon mosaic virus (WMV). Arch. Virol. 153, 1749-1754. 
Dogimont C., Bussemakers A., Martin J., Slama S., Lecoq H. and Pitrat M. (1997) Two complementary recessive genes conferring resistance to cucurbit aphid borne yellows luteovirus in an Indian melon line (Cucumis melo L.). Euphytica 96, 391-395.

Fabre, F., Chadœuf, J., Costa, C., Lecoq, H. and Desbiez, C. (2010) Asymmetrical overinfection as a process of plant virus emergence. J. Theor. Biol. 265, 377-388.

Gray, S.M., Moyer, J.W., Kennedy, G.G. and Campbell, C.L. (1986) Virus-suppression and aphid resistance effects on spatial and temporal spread of Watermelon Mosaic Virus-2. Phytopathology 76(11), 1254-1259.

Guiu-Aragones, C., Monforte, A.J., Saladie, M., Correa, R.X., Garcia-Mas, J. and MartinHernandez, A.M. (2014) The complex resistance to cucumber mosaic cucumovirus (CMV) in the melon accession PI161375 is governed by one gene and at least two quantitative trait loci. Mol. Breeding 34(2), 351-362.

Hooks, C.R.E. and Fereres, A. (2006) Protecting crops from non-persistently aphid-transmitted viruses: a review on the use of barrier plants as a management tool. Virus Res. 120, 1-16

Juarez, M., Legua, P., Mengual, C.M., Kassem, M.A., Sempere, R.N., Gomez, P., Truniger, V. and Aranda, M.A. (2013) Relative incidence, spatial distribution and genetic diversity of cucurbit viruses in eastern Spain. Ann. Appl. Biol. 162(3), 362-370. 
Kassem, M.A., Gosalvez, B., Garzo, E.A.F., Gomez-Guillamon, M.L. and Aranda, M.A. (2015)

Resistance to Cucurbit aphid-borne yellows virus in melon accession TGR-1551. Phytopathology 105, 1389-1396.

Kassem, M.A., Juarez, M., Gómez, P., Mengual, C.M., Sempere, R.N., Plaza, M., Elena, S.F., Moreno, A., Fereres, A. and Aranda, M.A. (2013) Genetic Diversity and Potential Vectors and Reservoirs of Cucurbit aphid-borne yellows virus in Southeastern Spain. Phytopathology 103, 1188-1197.

Kassem, M.A., Sempere, R.N., Juarez, M., Aranda, M.A. and Truniger, V. (2007) Cucurbit aphid-borne yellows virus is prevalent in field-grown cucurbit crops of southeastern Spain. Plant Dis. 91(3), 232-238.

Klingler J., Powell G., Thompson G.A., Isaacs R. (1998) Phloem specific aphid resistance in Cucumis melo line AR5: effects on feeding behaviour and performance of Aphis gossypii. Entomol. Exp. Appl. 86, 79-88.

Knierim, D., Deng, T.C., Tsai, W.S., Green, S.K. and Kenyon, L. (2010) Molecular identification of three distinct Polerovirus species and a recombinant Cucurbit aphid-borne yellows virus strain infecting cucurbit crops in Taiwan. Plant Pathol. 59, 991-1002.

Lecoq, H. (1999) Epidemiology of Cucurbit aphid-borne yellows virus. In: Smith, A.G. and Barker, H. (Eds), The Luteoviridae. CAB International, Wallingford, UK, pp. 243-248. 
Lecoq, H., Bourdin, D., Wipf-Scheibel, C., Bon, M., Lot, H., Lemaire, O. and Herrbach, E. (1992) A new yellowing disease of cucurbits caused by a luteovirus, cucurbit aphid-borne yellows virus. Plant Pathol. 41, 749-761.

Lecoq, H., Cohen, S., Pitrat, M. and Labonne, G. (1979) Resistance to cucumber mosaic virus transmission by aphids in Cucumis melo. Phytopathology 69, 1223-1225.

Lecoq, H. and Desbiez, C. (2012) Viruses of cucurbit crops in the Mediterranean region: an ever-changing picture. Adv. Virus Res. 84, 67-126.

Lecoq, H., Fabre, F., Joannon, B., Wipf-Scheibel, C., Chandeysson, C., Schoeny, A. and Desbiez, C. (2011) Search for factors involved in the rapid shift in watermelon mosaic virus (WMV) populations in south-eastern France. Virus Res. 159, 115-123.

Lecoq, H., Labonne, G. and Pitrat M. (1980) Specificity of resistance to virus transmission by aphids in Cucumis melo. Ann. Phytopathol. 12, 139-144.

Lecoq, H. and Pitrat, M. (1983) Field experiments on the integrated control of aphid-borne viruses in muskmelon. In: Plumb, R. T. and Thresh, J. M. (Eds.), Plant Virus Epidemiology. Blackwell Scientific Publications, Oxford, pp. 169-176.

Lecoq, H. and Pitrat, M. (1989) Effects of resistance on the epidemiology of virus diseases of cucurbits. In: Thomas, C. (Ed), Proceedings of Cucurbitaceae '89: Evaluation and enhancement of cucurbit germplasm'. USDA, Charleston, USA, pp. 40-48. 
Lecoq, H., Wipf-Scheibel, C., Chandeysson, C., Le Van, A., Fabre, F. and Desbiez, C. (2009) Molecular epidemiology of Zucchini yellow mosaic virus in France: An historical overview. Virus Res. 141, 190-200.

Lecoq, H., Wipf-Scheibel, C., Nozeran, K., Millot, P. and Desbiez, C. (2014) Comparative molecular epidemiology provides new insights into Zucchini yellow mosaic virus occurrence in France. Virus Res. 186, 135-143.

Lopez-Moya, J.-J., Wang, R.Y. and Pirone, T.P. (1999) Context of the coat protein DAG motif affects potyvirus transmissibility by aphids. J. Gen. Virol. 80, 3281-3288.

Martin, D.P., Murrell, B., Golden, M., Khoosal, A. and Muhire, B. (2015) RDP4: Detection and analysis of recombination patterns in virus genomes. Virus Evol. 1(1), 1-5.

Nutter, F.W.J. (1997) Quantifying the temporal dynamics of plant virus epidemics: a review. Crop Prot. 16, 603-618.

Pfiffner, L. and Wyss, E. (2004) Use of sown wildflower strips to enhance natural enemies of agricultural pests. In: Gurr, G. M., Wratten, S. D. and Altieri, M. A. (Eds.), Ecological engineering for pest management. Advances in habitat manipulation for arthropods. CSIRO Publishing, Australia, pp. 167-188.

Pitrat, M. and Lecoq, H. (1980) Inheritance of resistance to cucumber mosaic virus transmission by Aphis gossypii in Cucumis melo. Phytopathology 70, 958-961. 
Pitrat, M. and Lecoq, H. (1982) Genetic relations between non-acceptance and antibiosis resistance to Aphis gossypii in melon: Search for linkage with other genes. Agronomie 2, 503508.

Popp, J. and Hantos, K. (2011) The impact of crop protection on agricultural production. Stud. Agric. Econ. 113, 47-66.

Soosaar, J.L.M., Burch-Smith, T.M. and Dinesh-Kumar, S.P. (2005) Mechanisms of plant resistance to viruses. Nature Rev. Microbiol. 3(10), 789-798.

Tamura, K., Stecher, G., Peterson, D., Filipski, A. and Kumar, S. (2013) MEGA6: Molecular Evolutionary Genetics Analysis version 6.0. Mol. Biol. Evol. 30, 2725-2729.

Thomas, S., Boissot, N. and Vanlerberghe-Masutti, F. (2012) What do spring migrants reveal about sex and host selection in the melon aphid? BMC Evol. Biol. 12(47), 1-16

Waterworth, H.E. and Hadidi, A. (1998) Economic Losses Due to Plant Viruses. In: Hadidi, A., Khetarpal, R.K. and Koganezawa, H. (Eds.), Plant Virus Disease Control, APS Press, Saint Paul, 1-13. 
Table 1: Melon planting and virus sampling details for field trials conducted in Avignon between 2011 and 2015

\begin{tabular}{llllll}
\hline $\begin{array}{l}\text { Trial } \\
\text { code }\end{array}$ & $\begin{array}{l}\text { Date of } \\
\text { planting }\end{array}$ & $\begin{array}{l}\text { Date of } \\
\text { first } \\
\text { sampling }\end{array}$ & $\begin{array}{l}\text { Number of } \\
\text { sampling } \\
\text { dates }\end{array}$ & $\begin{array}{l}\text { Number of } \\
\text { plants } \\
\text { per modality }\end{array}$ & $\begin{array}{l}\text { Number of plants sampled } \\
\text { per modality per date } \\
\text { (sampling effort } \%)\end{array}$ \\
\hline V11 & $09 / 05 / 11^{*}$ & $16 / 05 / 11$ & 10 & 120 & $24(20 \%)$ \\
V12 & $11 / 05 / 12^{*}$ & $21 / 05 / 12$ & 8 & 150 & $24(16 \%)$ \\
V13 & $06 / 05 / 13^{*}$ & $13 / 05 / 13$ & 11 & 150 & $24(16 \%)$ \\
P11 & $24 / 05 / 11$ & $31 / 05 / 11$ & 9 & 208 & $40(19 \%)$ \\
P12 & $31 / 05 / 12$ & $06 / 06 / 12$ & 8 & 240 & $40(17 \%)$ \\
P13 & $24 / 05 / 13$ & $19 / 06 / 13$ & 7 & 240 & $32(13 \%)$ \\
P14 & $27 / 05 / 14$ & $04 / 06 / 14$ & 8 & 240 & $40(17 \%)$ \\
P15 & $28 / 05 / 15$ & $05 / 06 / 15$ & 8 & 240 & $40(17 \%)$ \\
\hline
\end{tabular}

*Agryl P17 fleece removal; fleece optimizes plant growth by increasing both air and soil

temperatures and reducing wind damage 
Table 2: Number of CABYV and WMV isolates sequenced from different trials and years.

Isolates were obtained from epidemics on melons crops with $(\mathrm{R})$ or without $(\mathrm{S})$ the Vat gene in eight field trials conducted in Avignon between 2011 and 2015.

\begin{tabular}{|c|c|c|c|c|}
\hline \multirow[b]{2}{*}{ Year (corresponding trials) } & \multicolumn{2}{|c|}{ CABYV } & \multicolumn{2}{|c|}{ WMV } \\
\hline & $\mathrm{R}$ & $\mathrm{S}$ & $\mathrm{R}$ & $\mathrm{S}$ \\
\hline $2011(\mathrm{P} 11+\mathrm{V} 11)$ & 20 & 24 & 28 & 22 \\
\hline 2012 (P12+V12 & 11 & 17 & 34 & 19 \\
\hline 2013 (P13+V13) & 23 & 23 & 33 & 39 \\
\hline $2014(\mathrm{P} 14)$ & 9 & 15 & 24 & 29 \\
\hline 2015 (P15) & 16 & 35 & 34 & 37 \\
\hline Total & 79 & 114 & 153 & 146 \\
\hline
\end{tabular}


Table 3: Parameter estimates of virus disease progress curves and mean incidence on melons crops with (R) or without (S) the Vat gene in eight field trials conducted in Avignon between 2011 and 2015. The p-value of the sign test performed between $\mathrm{R}$ and $\mathrm{S}$ values is given in bold.

\begin{tabular}{|c|c|c|c|c|c|c|c|c|c|}
\hline \multirow[b]{3}{*}{ Virus } & \multirow[b]{3}{*}{ Trial } & \multicolumn{6}{|c|}{ Parameter $^{\mathrm{x}}$} & \multirow{2}{*}{\multicolumn{2}{|c|}{$\begin{array}{c}\text { Mean } \\
\text { incidence }(\%)^{\mathrm{y}}\end{array}$}} \\
\hline & & \multicolumn{2}{|c|}{$\alpha$} & \multicolumn{2}{|c|}{$\beta$} & \multicolumn{2}{|c|}{$\gamma$} & & \\
\hline & & $\mathrm{R}$ & $S$ & $\mathrm{R}$ & $\mathrm{S}$ & $\mathrm{R}$ & $\mathrm{S}$ & $\mathrm{R}$ & $S$ \\
\hline \multirow[t]{9}{*}{ CABYV } & V11 & 0.0071 & 0.0237 & 8 & 176 & 100 & 100 & 38.3 & 55.7 \\
\hline & V12 & 0.0041 & 0.0052 & 7 & 4 & 100 & 92 & 11.6 & 27.1 \\
\hline & V13 & 0.0129 & 0.0187 & 58 & 135 & 96 & 96 & 24.8 & 33.5 \\
\hline & $\mathrm{P} 11$ & 0.0159 & 0.0204 & 17 & 16 & 100 & 100 & 58.7 & 66.8 \\
\hline & $\mathrm{P} 12$ & 0.0097 & 0.0119 & 7 & 8 & 65 & 87 & 33.6 & 49.2 \\
\hline & $\mathrm{P} 13$ & 0.0074 & 0.0111 & 13 & 21 & 87 & 89 & 19.3 & 28.8 \\
\hline & P14 & 0.0039 & 0.0073 & 8 & 10 & 100 & 81 & 14.5 & 29.6 \\
\hline & $\mathrm{P} 15$ & 0.0091 & 0.0103 & 21 & 13 & 61 & 100 & 23.3 & 51.4 \\
\hline & p-value & \multicolumn{2}{|c|}{0.008} & \multicolumn{2}{|c|}{$>0.10$} & \multicolumn{2}{|c|}{$>0.10$} & \multicolumn{2}{|c|}{0.008} \\
\hline \multirow[t]{9}{*}{ CMV } & V11 & 0.0142 & 0.0095 & 51 & 17 & 9 & 37 & 3.7 & 13.6 \\
\hline & V12 & 0.0214 & 0.0368 & 91 & 1065 & 88 & 100 & 41.4 & 54.4 \\
\hline & V13 & 0.0116 & 0.0147 & 79 & 199 & 81 & 98 & 16.3 & 21.0 \\
\hline & $\mathrm{P} 11$ & $\mathrm{nd}^{\mathrm{z}}$ & 0.0044 & nd & 21 & nd & 100 & 0.7 & 4.2 \\
\hline & $\mathrm{P} 12$ & 0.0176 & 0.0155 & 24 & 10 & 100 & 100 & 59.0 & 63.3 \\
\hline & $\mathrm{P} 13$ & 0.0226 & 0.0375 & 116 & 569 & 100 & 98 & 48.4 & 60.7 \\
\hline & $\mathrm{P} 14$ & 0.0183 & 0.0181 & 55 & 33 & 100 & 100 & 58.7 & 62.0 \\
\hline & P15 & 0.0182 & 0.0196 & 111 & 69 & 94 & 99 & 49.7 & 58.9 \\
\hline & p-value & \multicolumn{2}{|c|}{$>0.10$} & \multicolumn{2}{|c|}{$>0.10$} & \multicolumn{2}{|c|}{$>0.10$} & \multicolumn{2}{|c|}{0.008} \\
\hline \multirow[t]{9}{*}{ WMV } & V11 & 0.0062 & 0.0046 & 20 & 9 & 100 & 97 & 16.8 & 16.8 \\
\hline & V12 & 0.0070 & 0.0046 & 10 & 7 & 56 & 12 & 13.2 & 1.9 \\
\hline & V13 & 0.0180 & 0.0303 & 5835 & $1.1 \mathrm{e} 6$ & 78 & 84 & 7.8 & 10.6 \\
\hline & $\mathrm{P} 11$ & 0.0155 & 0.0106 & 1077 & 285 & 66 & 100 & 13.0 & 10.3 \\
\hline & $\mathrm{P} 12$ & 0.0124 & 0.0151 & 28 & 112 & 77 & 88 & 32.8 & 33.3 \\
\hline & $\mathrm{P} 13$ & 0.0363 & 0.0254 & $9.5 \mathrm{e} 5$ & 21794 & 100 & 100 & 22.6 & 20.1 \\
\hline & P14 & 0.0141 & 0.0165 & 228 & 142 & 100 & 98 & 29.8 & 43.4 \\
\hline & $\mathrm{P} 15$ & 0.0339 & 0.0257 & 50078 & 3933 & 99 & 99 & 45.1 & 45.7 \\
\hline & p-value & \multicolumn{2}{|c|}{$>0.10$} & \multicolumn{2}{|c|}{$>0.10$} & \multicolumn{2}{|c|}{$>0.10$} & \multicolumn{2}{|c|}{$>0.10$} \\
\hline
\end{tabular}

\footnotetext{
${ }^{\mathrm{x}}$ Parameters were estimated by fitting the Gompertz model to observed data:
}

$y_{t}=\gamma e^{-\beta e^{-\alpha t}}$ 
in which $\mathrm{y}_{\mathrm{t}}$ is the incidence expressed as a percentage and $\mathrm{t}$ is the thermal time expressed in degree-days (basis $12^{\circ} \mathrm{C}$ ); $\alpha$ is linked to disease progress: when $\alpha$ increases, the epidemic is more rapid; $\beta$ is linked to disease onset: when $\beta$ increases, the epidemic is delayed; $\gamma$ is the asymptote, i.e., the carrying capacity: when $\gamma$ increases, maximum incidence is raised.

y The mean incidence over the epidemic was approximated by the area under the disease progress curve (AUDPC) standardized by the total duration of the monitoring in each trial. On the basis of their mean incidence, viral epidemics were categorized as mild [0-20\%], intermediate [21-40\%], severe [41-60\%] or extreme [61-100\%].

${ }^{\mathrm{z}} \mathrm{nd}=$ not determined (procedure NLIN failed to converge) 
Table 4: P-values for the effect of Vat on the probability of infection of one melon plant by a given virus in eight field trials conducted in Avignon between 2011 and 2015. P-values in bold represent a significant effect of Vat. Unless otherwise noted, Vat reduces the probability of infection.

\begin{tabular}{lccc}
\hline & \multicolumn{3}{c}{ Virus } \\
\cline { 2 - 4 } Trial & CABYV & CMV & WMV \\
\hline V11 & $\mathbf{0 . 0 0 0 5}$ & $\mathbf{0 . 0 1 9 7}$ & $>0.10$ \\
V12 & $\mathbf{0 . 0 2 3 0}$ & $\mathbf{0 . 0 0 8 8}$ & $\mathbf{0 . 0 0 5 8 *}$ \\
V13 & $\mathbf{0 . 0 5 3 0}$ & $\mathbf{0 . 0 3 8 7}$ & $>0.10$ \\
P11 & $\mathbf{0 . 0 0 1 3}$ & $\mathbf{0 . 0 2 0 3}$ & $>0.10$ \\
P12 & $\mathbf{0 . 0 0 7 7}$ & $>0.10$ & $>0.10$ \\
P13 & $\mathbf{0 . 0 0 2 8}$ & $\mathbf{0 . 0 0 0 7}$ & 0.0966 \\
P14 & $\mathbf{0 . 0 0 8 3}$ & $>0.10$ & $\mathbf{0 . 0 0 0 7}$ \\
P15 & $<\mathbf{0 . 0 0 0 1}$ & $\mathbf{0 . 0 0 6 3}$ & $>0.10$ \\
\hline
\end{tabular}

$*(\mathrm{R}>\mathrm{S})$ 


\section{Figure legends}

Figure 1: CABYV disease progress in melon crops with $(\mathrm{R})$ or without $(\mathrm{S})$ the Vat gene in eight field trials conducted in Avignon between 2011 and 2015. Symbols represent observed mean incidences for each treatment. Lines are fitted curves (Gompertz model).

Figure 2: CMV disease progress in melon crops with (R) or without (S) the Vat gene in eight field trials conducted in Avignon between 2011 and 2015. Symbols represent observed mean incidences for each treatment. Lines are fitted curves (Gompertz model).

Figure 3: WMV disease progress in melon crops with $(\mathrm{R})$ or without $(\mathrm{S})$ the Vat gene in eight field trials conducted in Avignon between 2011 and 2015. Symbols represent observed mean incidences for each treatment. Lines are fitted curves (Gompertz model).

Figure 4: (a) Haplotypic network based on 193 partial CABYV sequences obtained from field trials conducted in Avignon between 2011 and 2015. Each pattern corresponds to a different haplotype. Branch lengths are proportional to the number of mutations between haplotypes; the scale bar represents one mutation. Node sizes are related to the number of isolates sharing the same haplotype. (b) Frequency of the different CABYV haplotypes in melon plants with (R) or without (S) the Vat gene

Figure 5: Distance tree based on partial CP/MP coding nucleotide sequences for the $13 \mathrm{CABYV}$ haplotypes observed on melon plants with $(\mathrm{R})$ or without $(\mathrm{S})$ the Vat gene in field trials conducted in Avignon between 2011 and 2015. Genbank accession numbers and geographic origin of the isolates are indicated on the tree. Bootstrap values ( $\mathrm{n}=500$ bootstraps) above $50 \%$ 
are indicated for each node. The asterisk indicates the «Spanish » subgroup containing haplotype G.

Figure 6: Distance tree based on partial Nib-CP coding nucleotide sequences for the $27 \mathrm{WMV}$ haplotypes observed on melon plants with (R) or without (S) the Vat gene in field trials conducted in Avignon between 2011 and 2015. Bootstrap values ( $\mathrm{n}=500$ bootstraps) above $80 \%$ are indicated for each node. Reference isolates are framed for each subgroup.

Figure 7: Frequency of the different WMV molecular groups observed in melon plants with (R) or without (S) the Vat gene in field trials conducted in Avignon between 2011 and 2015 
Figure 1
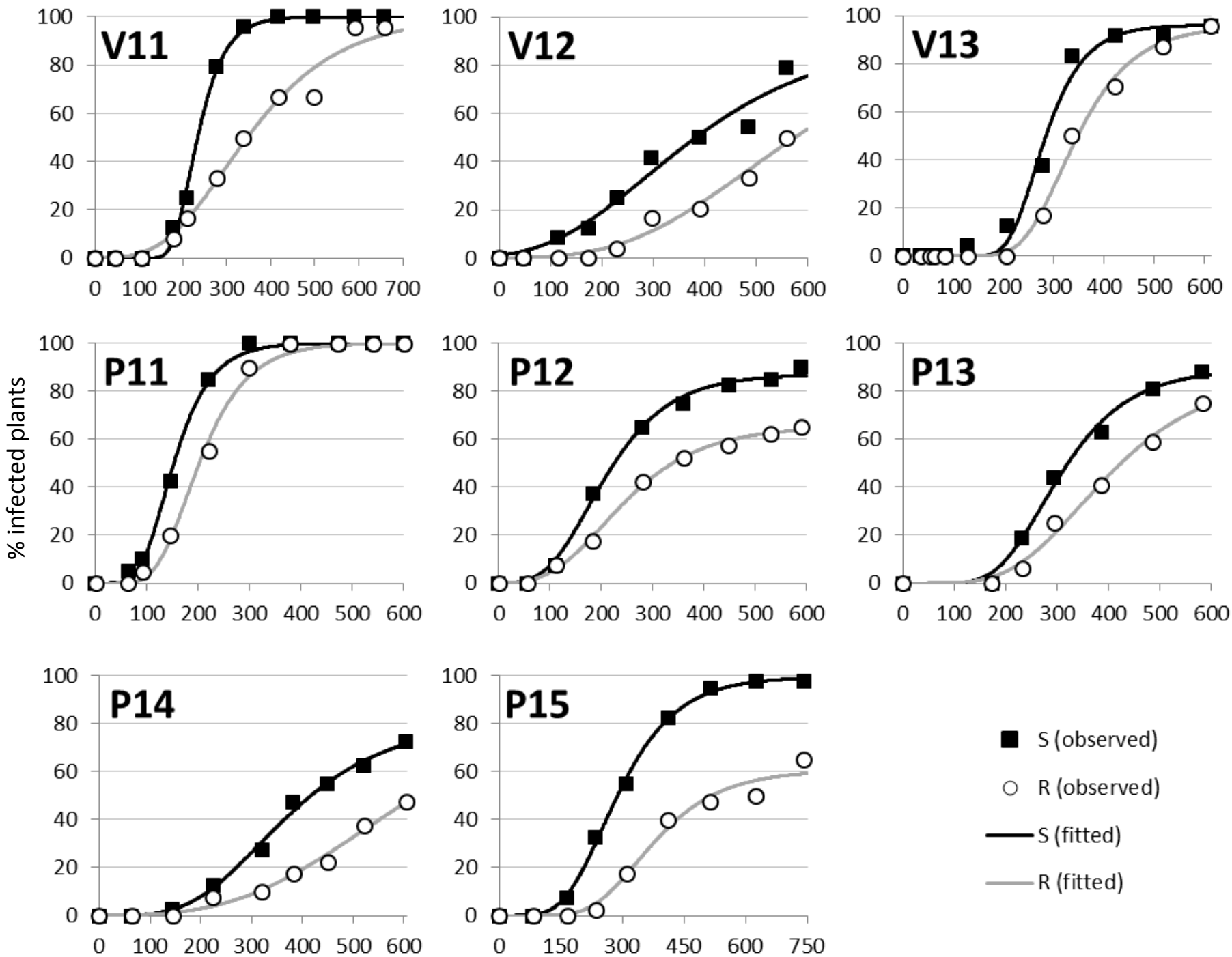

- S(observed)

O R (observed)

- $\mathrm{S}$ (fitted)

- $\mathrm{R}$ (fitted)

Time after planting (degree-days, basis $12^{\circ} \mathrm{C}$ ) 
Figure 2
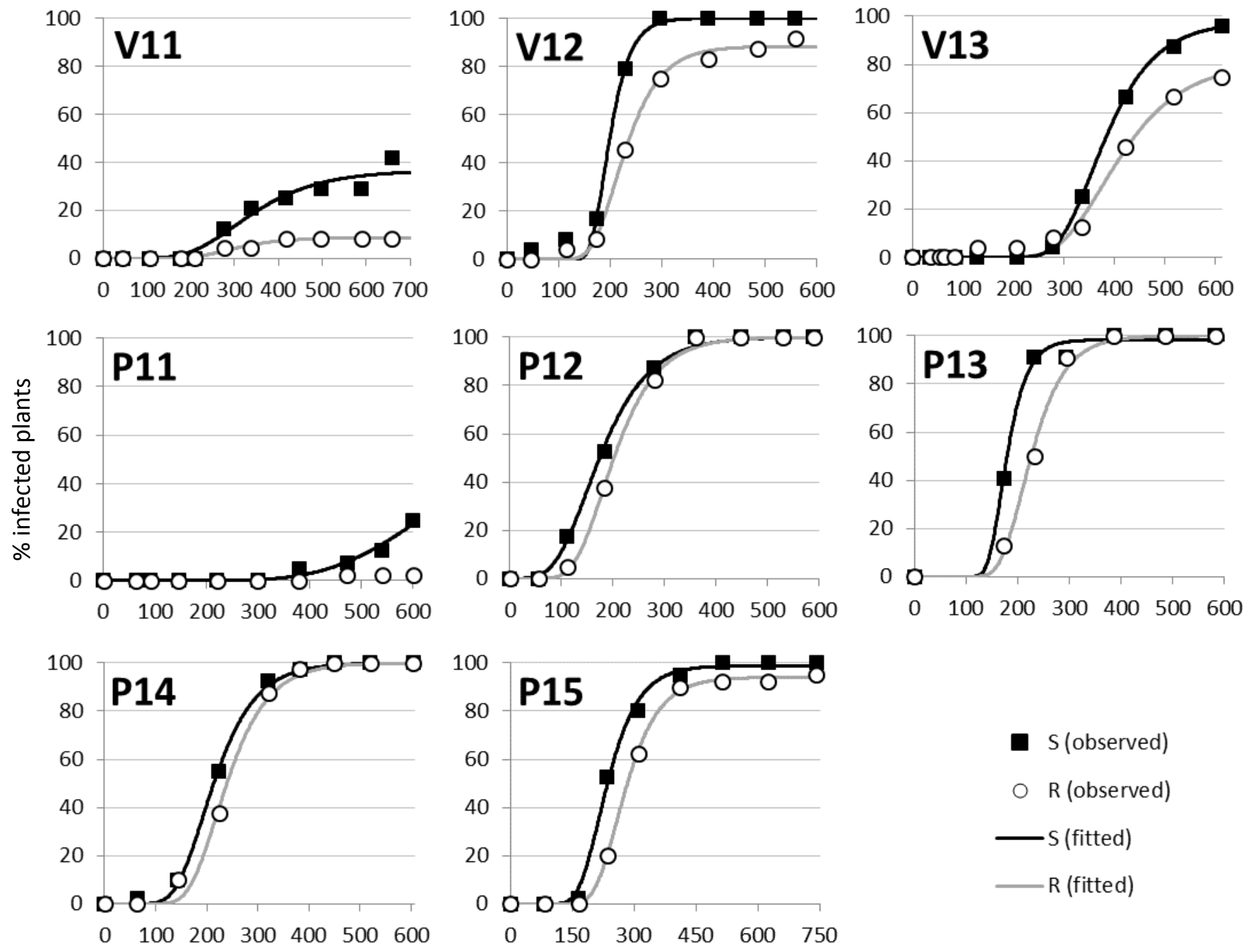

Time after planting (degree-days, basis $12^{\circ} \mathrm{C}$ ) 
Figure 3
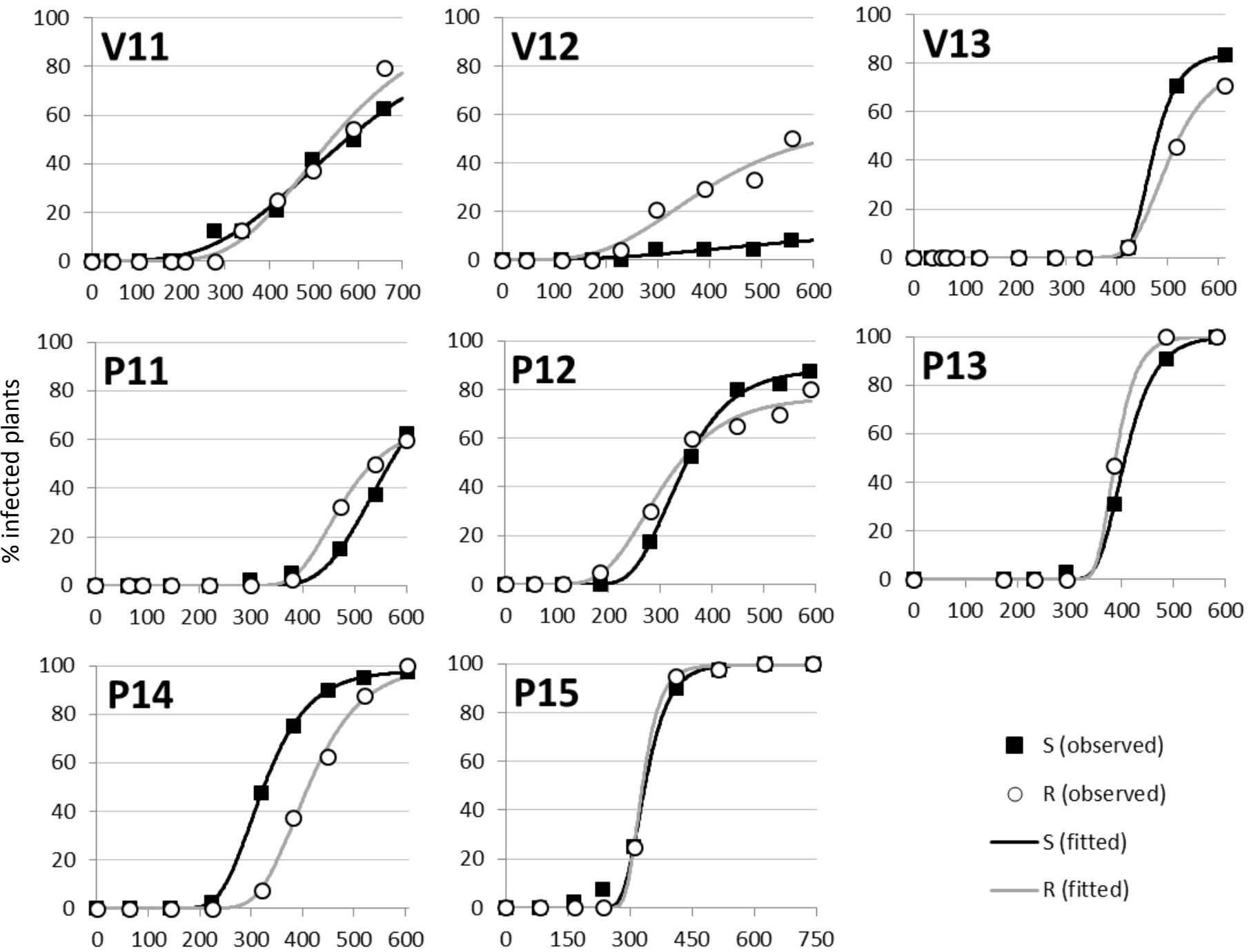

S (observed)

R (observed)

$\longrightarrow \mathrm{S}$ (fitted)

R (fitted)

Time after planting (degree-days, basis $12^{\circ} \mathrm{C}$ ) 
Figure 4

(a)

(b)
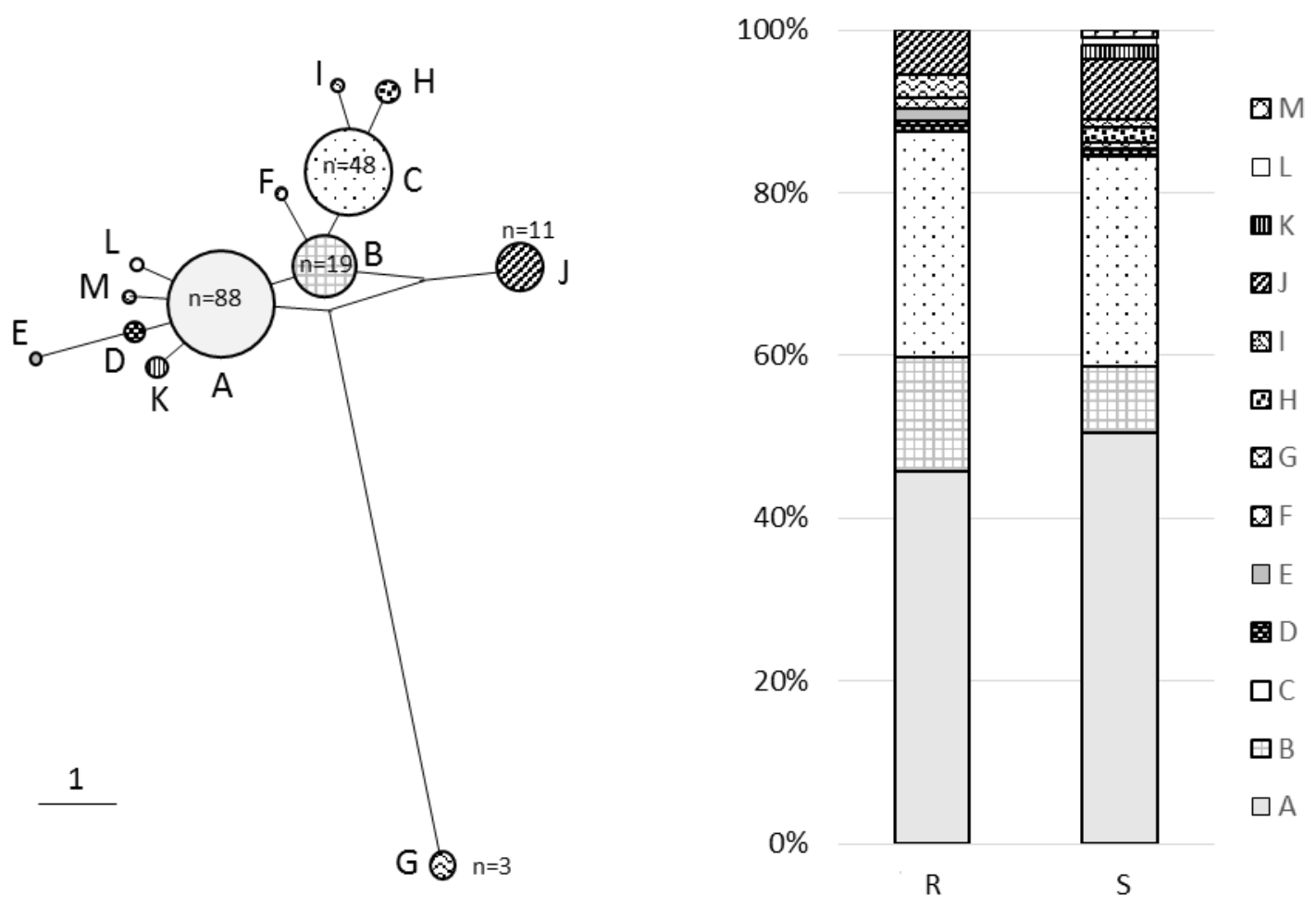
Figure 5

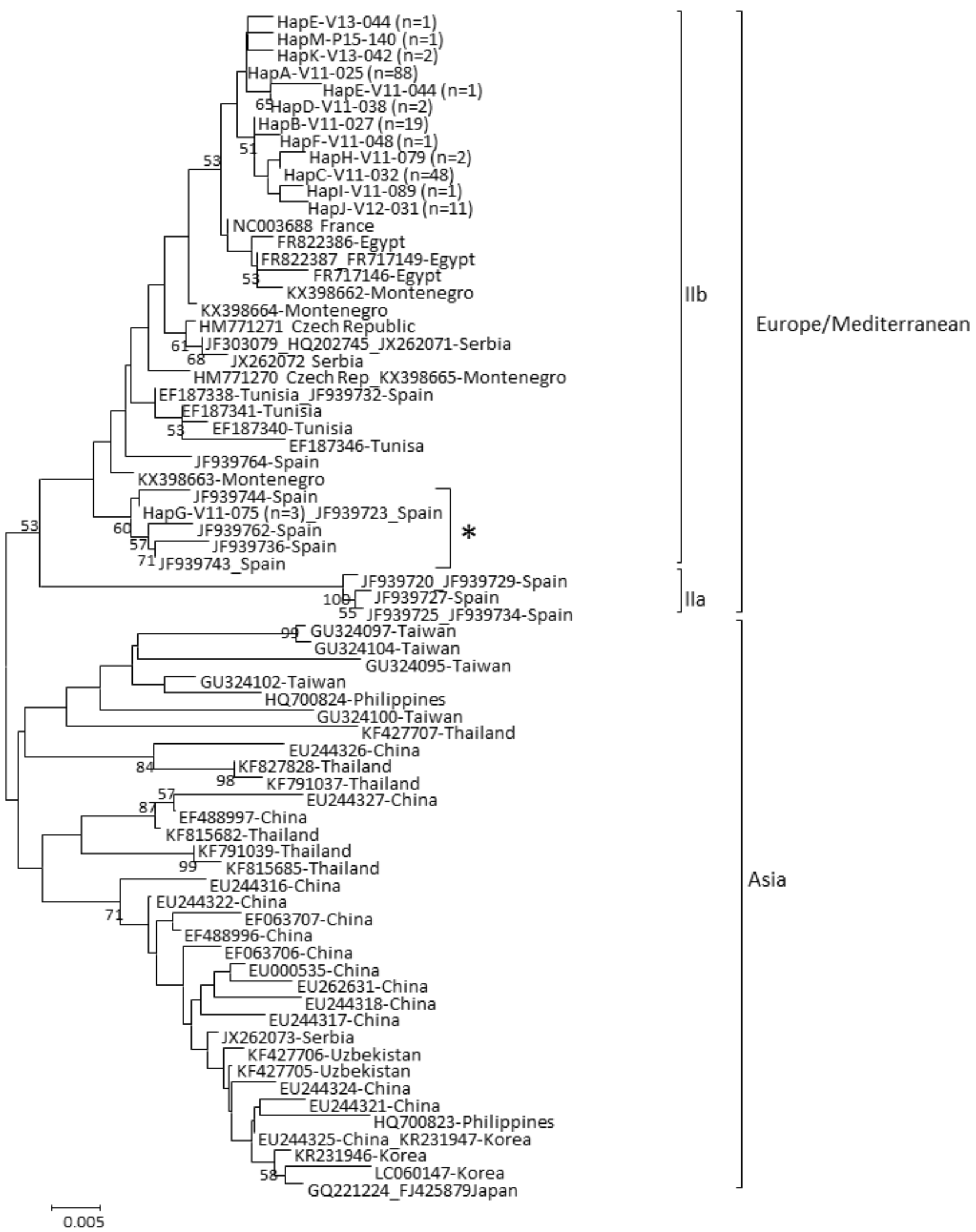


Figure 6
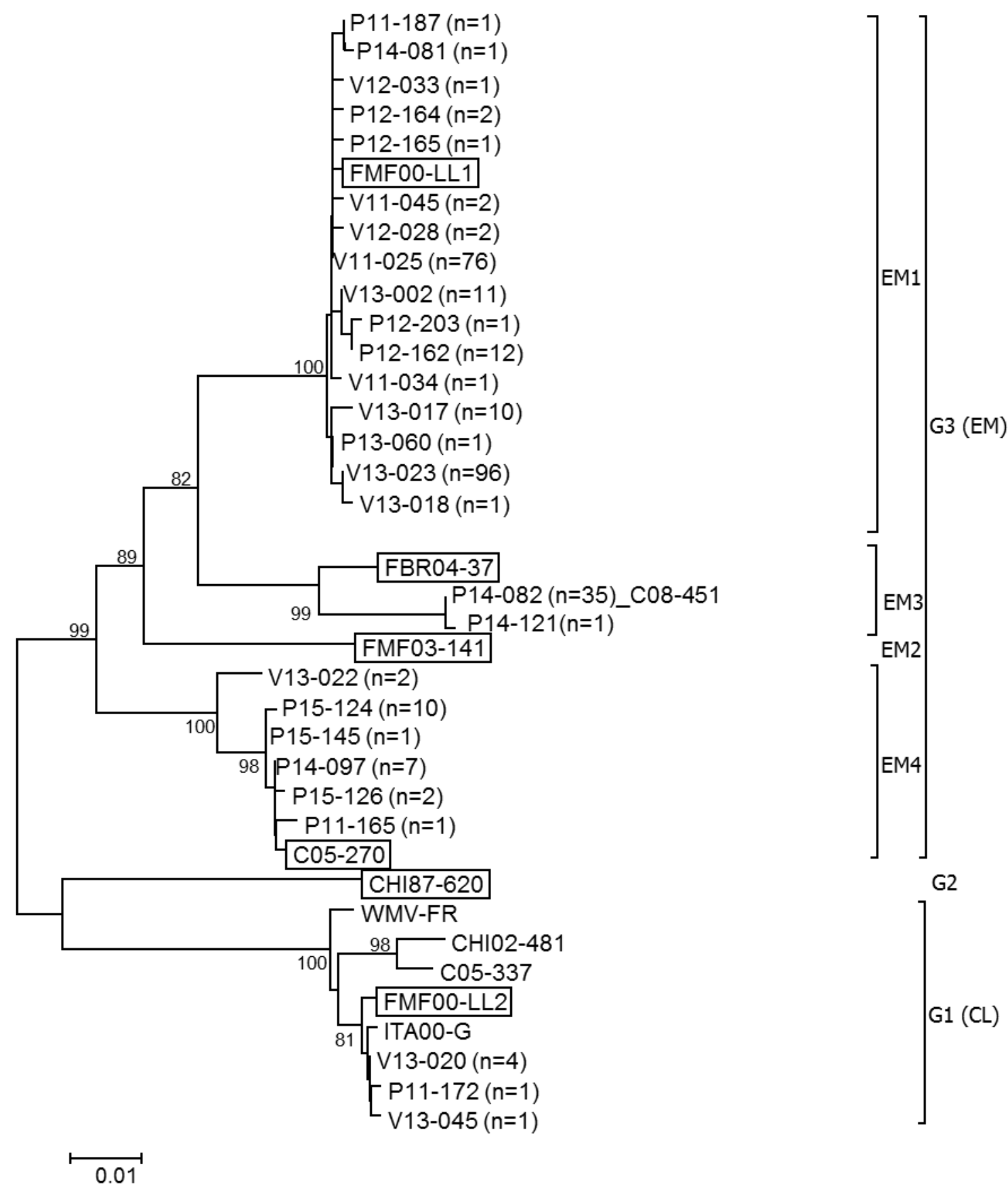
Figure 7

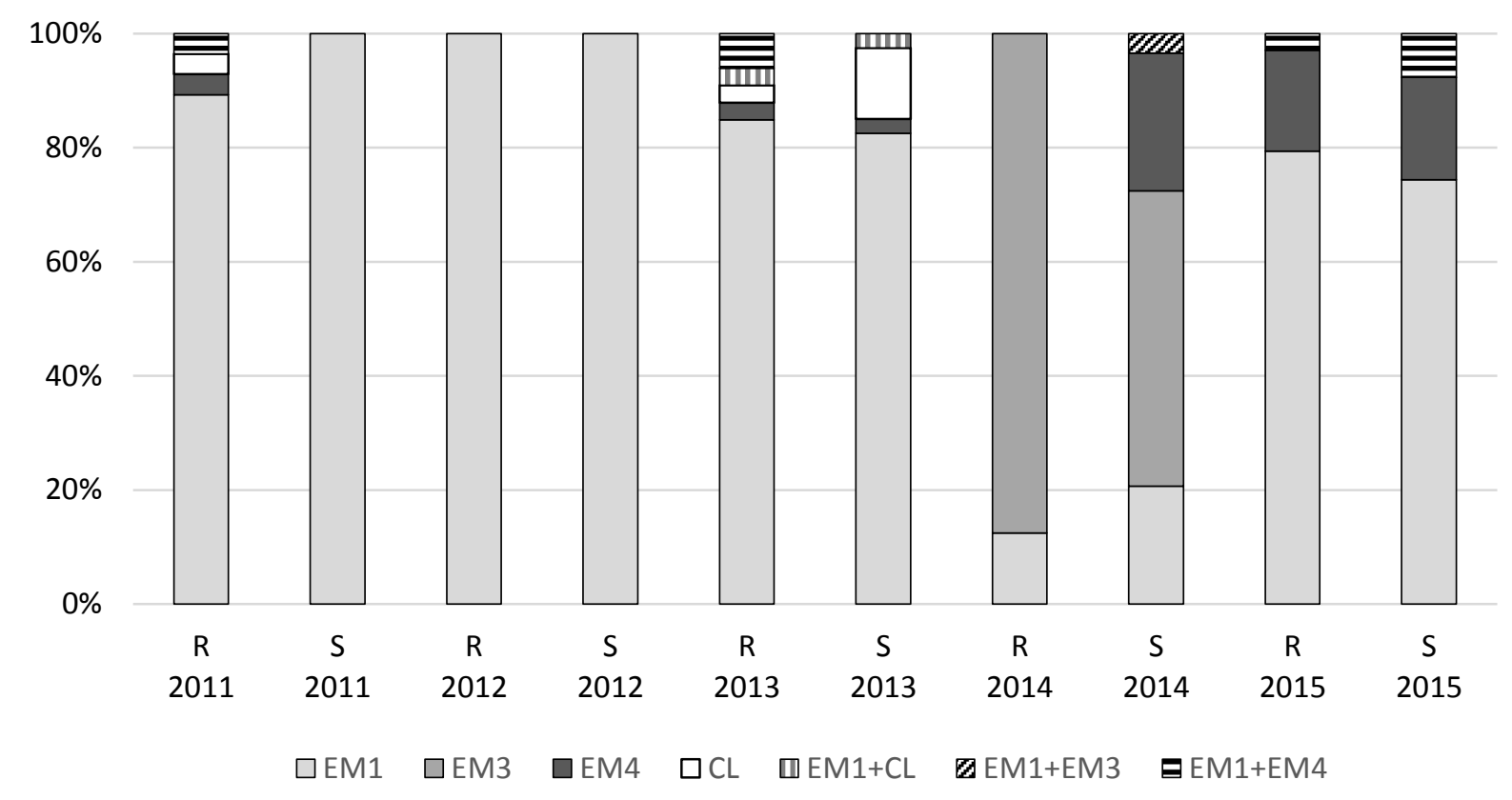

